DOI 10.47649/vau.2020.v59.i4.16

УДК 347.1

МРНТИ 340.1(075.8)

\author{
A.Omarov ${ }^{1}$, A.Kultasov ${ }^{1}$, K.Abdilov ${ }^{2}$ \\ ${ }^{1}$ Kokshetau State University named after Sh. Ualikhanov \\ Kokshetau, Kazakhstan \\ ${ }^{1}$ Kokshetau State University named after Sh. Ualikhanov \\ Kokshetau, Kazakhstan \\ ${ }^{2}$ Eurasian National University named after L.N. Gumilyov \\ Nur-Sultan, Kazakhstan \\ E-mail:Omarov 8@mail.ru
}

\title{
A COMPARISON OF THE COMMON LAW BASED DUTY WITH ITS CIVIL LAW EQUIVALENT
}

The article discusses the features of civil law in different countries. The authors studied the origins of the modern tradition of civil law, comparing the legal systems of two European countries. One of the traditional classifications of duties in civil law is analyzed, the conclusion is made about the inappropriateness of the allocation of personal and universal duties.

In comparative law, there are many situations where the same legal term has different meanings, or where different legal terms have same legal effect. This confusion most often occurs when civil lawyers have to deal with common law, or vice versa, when common law lawyers deal with civil law issues. While there are many issues which are dealt with in the same way by the civil law and common law systems, there remain also significant differences between these two legal systems related to legal structure, classification, fundamental concepts, terminology, etc.

As lawyers know, legal systems in countries around the world generally fall into one of two main categories: common law systems and civil law systems. There are roughly 150 countries that have what can be described as primarily civil law systems, whereas there are about 80 common law countries. The main difference between the two systems is that in common law countries, case law - in the form of published judicial opinions - is of primary importance, whereas in civil law systems, codified statutes predominate.

Key words: civil law, legal jurisdiction, civil obligations, classification of civil obligations.

A comparison of the duty between two legal systems may seem a hard task by reason of that there is no single civil law, which can fall under comparison, because of there is a variety of civil law models in different countries. As Vischer noted in his article that the notion of having a single civil law, respectively continental European law, may be compared to "grouping sea otters and ostriches merely because at some stage they both evolved from some primitive vertebrae".[1, $13,14]$ The divergence of civil law jurisdictions has resulted from the historical development. The continental European civil law is rooted in the time of reception of Roman law in the Middle Ages, leading to the ius commune. From this perspective, the national law models moved in different directions, having the Napoleonic codifications as one of the central pillar of the civil law development. [2, 401-404] One can say that most civil law jurisdictions belong to one of the two main civil law models: French and German. Even though, if someone reduced the variety of civil law jurisdictions to these two origins of modern civil law tradition, one would be able to state that the modern civil law has no singlelegal model, but two. Considering the French Code Civil (CC) and the German Bürgerliches Gesetzbuch (BGB), one can find common sense in the both codifications, but also substantial distinction between them. [3, 1-2] This infers a broader variety of legal paradigm than in the common law jurisdiction. It is also frequently observed that 
the classical common law states share one language. The civil law countries speak different languages, complicating the usage of court decisions from other countries as legal authority. Moreover, it must be taken into consideration that civil law does not concede the "stare decisis", which implicates that the courts apparently exercise diverging or new approaches to legal issues. The fact of the variety of civil law frameworks does not hide sharp distinctions between civil law and common law jurisdictions, and as a good example the absence of stare decisis in civil law model can be cited. Thus, from this perspective it can be stated that the civil law could be reviewed in general in comparison with the common law, taking into account such features (or its absence) which are shared by most civil law jurisdictions. Otherwise speaking, the substantial diversion among civil law jurisdictions is not the matter in regard to the comparison of the two systems. The matter is about features that are either shared or lacking under all civil law jurisdictions. [4, 74-76]

In Maume's view, the civil law jurisdictions lack the fiduciary principle; he argues that it is unique characteristic to the common law jurisdictions. [5, 191-233, 206] However, some academic scholars claim that fiduciary principleexists in both civil law and common law based jurisdictions. [6, 77] Maume does not agree with this proposition and, to this effect, he quotes Bebchuk and Roe who commented that "all advanced countries may recognize and accept a certain fiduciary principle, but countries A and B might implement it radically differently".[7, 550,551] Unequivocally, civil law based jurisdictions concede cases where one party places a higher level of trust on another party, causing certain duties and responsibilities. Though, from the historical perspective the civil law system did not contain any equivalent concept which could be accurately compared or equal to the status of a trustee or beneficiary. Drucker asserts that the term "fiduciary" has come from the pactum fiduciae under Roman law, so the common law and continental European law share the understanding of this term from that source. In principle, it is true that the notion of fiduciary trust exists in the civil law jurisdiction; $[8,53]$ it implicates the mechanism that offers an agreement under which property has been transferred from one individual to another individual. The new owner has full rights in respect to the property, however, being under contractual restraint from enjoying these rights as he sees proper.

On the first face, the understanding of fiducia in civil law seems similar to the concept of trust and fiduciary. However, the substantial distinction is that, unlike the fundamental principle under common law, the civil law jurisdiction does not recognise the "bifurcation of property", which breaks down the involved parties into categories of trustee and beneficiary. Conversely, the fiduciary relationship under the continental European law is basically regulated by contract and legislation. Reasoning to this diversion can be the fact that, unlike the UK law, continental law has not been exposed to a refinement of trust law since the later Middle Ages. It is true that the trust lawis one of the most significant legal instruments created by the law of equity, though the dualism of equity and common law never arose in continental Europe. Hence, none of the traditional civil law jurisdictions have the provision of a statute regulating matters on trusts.

Further, the civil law jurisdictions are traditionally based on the concept of codification, which implicates the regulation of most contractual legal relationships under statute, leaving room for the possibility to diverge from the statutory regulations by mutual agreement in certain circumstances. If, for instance, a director acts in the interests of a company his responsibilities do not arise from a fiduciary-like or trust-like situation, but from the regulations circumscribed by the statute. The development of this statue can be determined by different factors, such as the political situation, current social process and even notable judicial cases. In contrast, the fiduciary principle, under the common law, being a fundamental legal norm is not restricted to 
specific legal issues, but spans the whole legal system, defending itself from the political, legal, social and economic changes. As a result, the legal approach based on the civil law lacks the simplicity and clarity of the fiduciary principle. $[9,23]$

From this perspective, there arises a question: in what way are conflicts of interest situations regulated in civil law based jurisdictions? To answer this question one should consider, for details, German legislature as a typical civil law based jurisdiction. In common law, the duty of loyalty has a long tradition which is rooted in the $18^{\text {th }}$ century and the case law has considerably given it clear-cut contours. The duty applies broadly to situations when the director's own interests conflict, or potentially may conflict, with the interests of the company. The civil law based jurisdictions, conversely, neither have developedan overarching no-conflict rule nor have envisaged an explicit formulation of the duty in their legislation as a case with German civil law. [10, 206] However, having a two-tier board structure, German civil law typically uses the allocation of authorities between the different collegiate organs as a mechanism to avoid conflicts of interest situations that possibly makes sense of lacking some rules regulating conflicts of interest that are circumscribed by a one-tier board UK legal system.

The German stock Corporation law Aktiengesellschaft (AktG) allocates the authority between the management board, which runs the company, and the supervisory board, which supervises the management as well as takes participation in the strategic development of the company (pursuant to sections 76 and 111 of AtkG). Members of a management board can be equated to executive members of a directors' board. Mainly, managers' duties are regulated by section 93(1) of AktG. The section determines a comprehensive duty of care similar to the duty of care circumscribed by the common law. The AktG does not contain a duty of loyalty, a duty to avoid conflicts of interest situations as well as obligations to disclose such situations. In contrast, the AktG employs a "casuistic" approach, which implicates that the statutory regulations contain certain situations that may relate to conflicts of interest or other aspects, which give rise to the requirement that binding directors to be loyal. One can say that this is a rational explanation why the comprehensive principle of fiduciary duties are not prescribed in the civil law based statute. Section 93(1) of AktG, for instance, contains the duty of confidentiality and section 88(1) of AktG restrains directors from engaging in competition with the company lacking the supervisory board's authorisation, which implicitly stipulates a duty to disclose the competing activities. The AktG prescribes some other situations which basically relates to conflicts of interest, however, not requiring disclosure obligations. If a manager intends to enter into a contract with the company, the power to contract with the company is shifted from the management board to the supervisory board (pursuant to section 112 of AktG). However, the section 112 invokes only contracts, which implies it cannot be construed as dealing with every possible conflicts of interest situation.

Unlike with managers, supervisors do not fall under a no-competition rule (pursuant to section 105(2) of AktG). This more lenient approach in respect to conflicts of interest rests on the concept that a supervisor of the company will basically be an outside director with an unconnected primary occupation. Another aspect relating to this idea is section 100(2) of AktG that permits up to ten appointments holding the supervisor position in different companies. Scholars characterise this lenient approach as undoubtedly some kind of tolerance against conflicts, known as "Konflikttoleranz". [11, 697,700] The other certain rules regarding noconflicts of interestarise from the nature of two-tier board legal system. Supervisors cannot, for instance, hold manager's position in the same company and contrariwise (pursuant to section 105(1) of AktG).The fundamental distinction between the common law principles and the 
German AktG comes into the open when a supervisor of the company, whose position in the company is similar to the position of a non-executive director under the common law, has a conflict of interest. For instance, assuming that an individual is on the supervisory board of two different companies that making a contract among themselves. From this perspective, it would be reasonable that the supervisor would have to disclose the conflicts of interest situation and, consequently, need to abstain from voting in both companies regarding the relevant deal. According to the decision held by the Federal Court of Justice that, in that context, the supervisor would be held liable for compensation to the extent that he advised or voted in favour of a deal inflicting damage on one of the companies, which implicates a breach of the duty of care under sections 93 and 116 of AktG as well as the duty, under section 111 of AktG, stipulating the obligation of management's supervision. $[12,92]$ At the same time, the duty under section 111 would likewise prevent the supervisor from abstaining from voting regarding the deal since he had to carry out the duty to supervise the management proactively, enforcing a vote against the respective deal. Thus, conflicted supervisors would violate obligations under the duty owed, at least, to one of the companies, in case the conflicts of interest situation arises. Put it otherwise, if there is a conflict whatever the supervisor does, he would be held liable for a breach of his duties.

As a result, one can say that in civil law based jurisdictions all-encompassing no-conflict rule is not prescribed because of the separation of authority between two bodies. And it can be argued that the two-tier board legal system is more stringent than a widely defined and generally valid no-conflict doctrine in the common law, by reason of that the civil law merely relocates decision-making power. [13, 209] One finds it reasonable to assume that the civil law based legislature would have contained stricter duty of loyalty and duty to avoid conflicts of interest, if the fundamental principle of fiduciary duties was as wide-spread in the civil law based jurisdictions as it is in the common law based jurisdictions.[14, 57-61]

\section{References}

1 Vischer B. 'The Fiduciary in Continental Europe' [1999] Trust \& Trustees 13, 14

2 Frankel T. 'Towards Universal Fiduciary Principles' (2014) 39 Queen's Law Journal 391, 401-404

3 MatteiU.'Basic Issues of Private Law Codification in Europe: Trust' (2001) 1 Global Jurist Frontiers 1, 2

4 MaumeP. 'Conflict of interest and disclosure under company law: a continental-European perspective on legal origins' (2016) Journal of Corporate Law Studies, 16:1, 69-99, 74-76 at http://www.tandfonline.com/doi/abs/10.1080/14735970.2015.1101306 (last visited 19 June 2016)

5 Fleischer H. 'Legal Transplants in European Company Law: the Case of Fiduciary Duties' (2005) 2 European Company Law and Financial Law Review 378, 382 and also C. Gerner-Beuerle and E.P. Schuster, 'The Evolving Structure of Director's Duties in Europe' (2014) E.B.O.R., 15(2), 191-233, 206

6 Bebchuk L.A. and Roe M.J. 'A Theory of Path Dependence in Corporate Ownership and Governance' (1999) 52 Stanford Law Journal 127-170, 154 quoted in P. Maume, n 108 above, 77

7 Drucker A. 'Trusts on the Continental Europe' (1955) 4 International and Comparative Law Quarterly 550, 551 and also see P. Maume, n 108 above, 77

8 It can be found under German law and known as "fiduziarische Treuhand"

9 Maume P. n 108 above, 78-80 and also see M. Vranken, Fundamentals of European Civil Law (Federation Press, $2^{\text {nd }}$ ed., 2010), 23

10 Gerner C.Beuerle and E.P. Schuster, n 110 above, 206

11 Kokch J. 'Begriff und Rechtsfolgen von Interessenkonflikten und Unabhängigkeit im Aktienrecht' (2014) 43 Zeitschrift für Unternehmens- und Gesellschaftsrecht 697, 700 cited in P. Maume, n 108 above, 91

12 Federal Court of Justice, 21 December 1979, File No II ZR 244/78 and also see ibid, 92

13 Gerner C.Beuerle and Schuster E.P. n 110 above, 209

14 Vranken M. Fundamentals of European Civil Law (Federation Press, $2^{\text {nd }}$ ed., 2010, 57-61) 


\section{СРАВНЕНИЕ ОБЯЗАННОСТИ, ОСНОВАННОЙ НА ОБЩЕМ ПРАВЕ, С ЕГО ЭКВИВАЛЕНТОМ В ГРАЖДАНСКОМ ПРАВЕ}

В статье рассматриваются особенности гражданского права в разных странах. Авторами изучены истоки современной традиции гражданского права, сравниваются правовые системы двух европейских стран. Проанализирована одна из традиционных классификаций обязанностей в гражданском праве, сделан вывод о нецелесообразности выделения личных и универсальных обязанностей.

В сравнительном праве есть много ситуаций, когда один и тот же юридический термин имеет разные значения, или когда различные юридические термины имеют одинаковую юридическую силу. Эта путаница чаще всего возникает, когда гражданские юристы должны иметь дело с общим правом, или наоборот, когда юристы по общему праву имеют дело с вопросы гражданского права. Хотя есть много вопросов, которые решаются аналогичным образом Гражданское право и системы общего права, между этими две правовые системы, связанные с правовой структурой, классификацией, фундаментальными понятиями, терминология и т. д.

Как знают юристы, правовые системы в странах по всему миру обычно делятся на одну из двух основных категорий: системы общего права и системы гражданского права. Примерно 150 стран имеют то, что можно охарактеризовать как преимущественно системы гражданского права, тогда как существует около 80 стран общего права. Основное различие между двумя системами состоит в том, что в странах общего права прецедентное право - в форме опубликованных судебных заключений - имеет первостепенное значение, тогда как в системах гражданского права преобладают кодифицированные законы.

Ключевые слова: гражданское право, правовая юрисдикция, гражданско-правовые обязанности, классификация гражданско-правовых обязанностей.

\section{ЖАЛПЫ ҚҰҚЫҚТЫҚ МІНДЕТТЕМЕНІ ОНЫН АЗАМАТТЫҚ-ҚҰҚЫҚТЫК БАЛАМАСЫМЕН САЛЫСТЫРУ}

Мақалада әр түрлі елдердегі азаматтық құқықтың ерекшеліктері қарастырылады. Автор азаматтық құқықтың қазіргі заманғы дәстүрлерінің бастаулары зерттелді, екі еуропалық елдердің құқықтық жүйелері салыстырылады. Азаматтық құқықтағы міндеттердің дәстүрлі жіктемелерінің бірі талданды, жеке және әмбебап міндеттерді бөлудің орынсыздығы туралы қорытынды жасалды.

Салыстырмалы құқықта бірдей заңды термин әртүрлі мағынаға ие болатын немесе әртүрлі заңды терминдердің бірдей заңды күші болған кезде көптеген жағдайлар болады. Бұл шатасушылық көбінесе азаматтық заңгерлер жалпы құқық мәселелерімен айналысқанда немесе керісінше, жалпы заңгерлер азаматтық құқық мәселелерімен айналысқан кезде пайда болады. Азаматтық құқық пен жалпы құқық жүйелерінде ұқсас жолмен шешілетін көптеген мәселелер болғанымен, екі құқықтық жүйенің арасында құқықтық құрылым, негізгі ұғымдар, терминология және т.б. байланысты болады.

Заңгерлер білетіндей, дүниежүзі елдеріндегі құқықтық жүйелер, әдетте, екі негізгі категорияның біріне жатады: жалпы құқық жүйелері және азаматтық-құқықтық жүйелер. 150-ге жуық елде негізінен азаматтық-құқықтық жүйелер деп сипаттауға болады, ал 80-ге жуық қарапайым құқық елдері бар. Екі жүйенің басты айырмашылығы - жалпы құқық елдерінде сот практикасы - жарияланған сот пікірлері түрінде - бірінші орында, ал кодификацияланған заңдар азаматтық-құқықтық жүйелерде басым болады.

Негізгі сөздер: Азаматтық құқық, Құқықтық юрисдикция, азаматтық-құқықтық міндеттер, азаматтыққұқықтық міндеттердің жіктелуі.

\section{Information about authors:}

Azamat Omarov, Master of Laws, Senior Lecturer of the Department of Jurisprudence, NAO Kokshetau University. Research interests: civil legal relationshipE-mail: Omarov_8@mail.ru

Asylbek Kultasov, Master of Laws, Senior Lecturer of the Department of Jurisprudence, NAO Kokshetau University. Research interests: criminal law

Kanat Abdilov, PhD, Senior Lecturer at the Department of Law, Eurasian National University named after L.N. Gumilyov. Research interests: theory of state and law 